JPPIPA 8(1) (2020)

\title{
A Study of Content Analysis: Trends of Educational Research for Physics Courses in Indonesia
}

\author{
Rosa Safirotun Nabilah ${ }^{*}$, Jumadi ${ }^{1}$ \\ ${ }^{1}$ Department of Physics Education, Faculty of Mathematics and Natural Sciences, Universitas Negeri Yogyakarta, Indonesia
}

DOI: $\underline{10.29303 / \text { ippipa.v8i1.1293 }}$

\section{Article Info}

Received: December 26, 2021

Revised: January 24, 2022

Accepted: January 26, 2022

Published: January 31, 2022

\begin{abstract}
Physics educational research trends are always changing from time to time. This change follows the phenomenon of educational problems that are developing in the field. The current study is a content analysis of research to analyze the trends of physics educational research that was published between the years of 2018 and 2021, visualize physics educational research trends and how Indonesian researchers contribute to physics educational research. This research was reached through the Journal of Research in Science Education (JPPIPA). Data obtained is 48 data and taken with "physics education" as the keyword. It is aimed to guide the researchers who are planning to conduct studies in this particular field by specifying physics education in terms of their methods, subject areas, research titles, data analysis techniques, and sampling types. Based on the results of the research that has been carried out, it can be concluded that the trend of educational research has increased and is in great demand by researchers in 2021. The physics material that is the research trend is wave material. The subject variable that is often studied is research in the cognitive domain. The trend of physics education research tends to be research that uses quantitative research methods with quasi-experimental design and uses data collection instruments in the form of test instruments. The type of sampling used is school students both junior and senior high school. The trend of physics education research also tends to quantitative descriptive research with data analysis techniques using frequencies, percentages, and charts. Number author or authors are becoming a trend in physics education research as much as three and the number of research references are often used as reference only 1-30. The results of this analytical research can be used to guide and provide references for research that will be carried out by further researchers, especially in the field of physics education research.
\end{abstract}

Keywords: Physics education; Educational research; Content analysis; Scientific research methods

Citation: Nabilah, R. S., \& Jumadi, J. (2022). A Study of Content Analysis : Trends of Educational Research for Physics Courses in Indonesia. Jurnal Penelitian Pendidikan IPA, 8(1), 393-400. https://doi.org/10.29303/jppipa.v8i1.1293

\section{Introduction}

Life in the 21st century requires every individual to be able to think critically, creatively, innovatively, able to solve problems, make decisions, communicate, collaborate, work in teams, have a sense of responsibility, and master technology (Wijaya, et al., 2016; Asmawati, et al., 2018; Sulistyaningrum, et al., 2019). These desired demands in the 21st century are needed as an effort to increase human resources so that they can compete in the global era. The human resources needed are qualified and superior human resources in various ways. One of the skills needed in the 21st century can be mastered through education. Teaching and learning activities in schools carried out by students and teachers can improve these skills, one of which is through physics learning activities. This is in accordance with the opinion that physics learning in the global era of the 21st century is expected to be able to equip students to live a social life in society supported by skills 
honed during the learning process in class (Siswanto, 2020; Winarti, 2020; Mardhiyah, et al., 2021). In physics learning, students are required to understand the concepts that exist in natural phenomena that occur. Students are involved in the process of building a model that can help them to understand the relationships and differences between physical concepts in phenomena in nature.

Physics learning has goals including developing students' knowledge, understanding, and analytical skills towards the environment and surroundings (Azizah, et al., 2015). Physics learning in students is expected not only to master the concept but also apply the concepts they have understood in solving physics problems. However, classroom learning tends to emphasize mastery of concepts and overrides students' physics problem solving abilities. Physics is one of the subjects in the discipline of Natural Sciences which is still considered difficult by students (Istiyowati, et al., 2017; Sari, et al., 2018; Astalini, et al., 2019). This is supported by the results of a survey on research which shows that on average students are not interested in studying Physics, this is because Physics is a difficult subject to learn. This assumption indirectly forms understanding in students' thinking, so that students feel unable before studying and make students prefer memorizing formulas rather than prioritizing their understanding. Students who try to memorize Physics concepts and formulas without exploring their physical meaning will have difficulty in studying Physics. This is because memorizing formulas in studying Physics concepts will not help students in learning the meaning behind the use of these formulas. Physics material that is abstract is what makes students have to be able to understand concepts rather than just memorizing formulas.

In physics learning, students' problem-solving abilities are still relatively low (Hoellwarth, et al., 2005; Habibi, et at., 2017; Kalsum, et al., 2018). In working on physics problems given by the teacher, students more often directly use mathematical equations without analyzing, guessing the formula used and memorizing examples of questions that have been done to work on other questions. Students have difficulty when dealing with complex problems. Students are able to solve simple quantitative problems but lack the ability to solve more complex problems (Redish, 2005). Students have difficulty because the strategies taught in learning are only to solve problems that require mathematical calculations alone (Ogilvie, 2009). In fact, one of the goals of learning physics is to create people who can solve complex problems by applying their knowledge and understanding to everyday situations.

Learning difficulties can be interpreted as conditions in the learning process marked by certain obstacles to achieving learning outcomes (Abbas \&
Hidayat, 2018). These barriers may be realized and may not be realized and can be sociological, psychological or psychological in the whole learning process. People who experience obstacles in the process of achieving learning outcomes will get results below what they should be. Based on the many problems found in learning physics, there are many researchers both from prospective teachers, teachers and researchers who are interested in discussing and solving problems and phenomena that occur in learning physics. The research studied on physics learning uses various research methods, the methods used are quantitative, qualitative, mixed methods, and Research \& Development (R\&D) methods. The results of research from various problems and phenomena that exist in physics are very helpful in solving problems that exist in learning physics so as to provide solutions and alternatives in learning. The results of research conducted by researchers will be even more useful if they are widely published, for example into scientific journals so that research conducted by researchers can be applied in various places that have problems that are in accordance with the research carried out.

Scientific publications are the main performance indicators of academics. The results of research are not meaningful without a publication, whether published in online media or other print media (Darmalaksana \& Suryana, 2018). Scientific publications referred to here are publishing research papers in national or international journals on-line or based on OJS (open journal system). Publication of scientific journals is one way to increase the benefits of research results that have an impact on the improvement and benefit of society. Scientific publications are not only limited to scientific journals but can be done in the form of seminars, proceedings, publications, articles, which allow research results to be disseminated to the public openly, both on an international, national, regional and local scale.

There are various scientific journals about learning Physics that can overcome existing problems and phenomena so that they can be applied in schools later. From the existing scientific journals, it can also be seen what research scopes have been carried out by researchers in learning (Goktas, et al., 2012; Dinçer, 2018; Arici, 2019; Borenstein, et al., 2021), so that in the future new ideas and innovations will emerge that will be investigated by other researchers. With the existence of various scientific journals about learning but the absence of publications on the analysis of research trends published in Indonesia, especially in the Journal of Research of Science Education (JPPIPA) so there is no definite data on how research trends, especially those related to Physics education at JPPIPA. 


\section{Method}

The type of research used in this research is qualitative research with content analysis techniques. Content analysis can be defined as a technique of collecting and analyzing the content of a text which can be in the form of words, meanings, images, symbols, ideas, themes, or several messages that can be communicated (Calik \& Sözbilir, 2014; Martono, 2016; Patonah, et al., 2018). The data obtained will be analyzed by descriptive statistics of percentages using the frequency formula divided by the total number of data multiplied by 100 percent (Sudjana \& Ibrahim, 2004).

The data collection technique in content analysis is carried out by collecting articles that are the sample, in this case the research sample is Scientific Writing (Jurnal of Physics Education) available in the Journal of Research of Science Education (JPPIPA) UNRAM published from 2018 to 2021. Data was collected by recording various articles related to Physics education in the Journal of Research of Science Education (JPPIPA) and then taking data from these journals based on the indicators contained in the instruments used in this study.

Table 1. The following are the indicators used to collect data in the study

\begin{tabular}{l}
\hline Indicator \\
\hline Publication year \\
Physics subject titles \\
Variable research \\
Research methods \\
Research models \\
Data collection instruments \\
Sampling type and size \\
Data analysis techniques and numbers \\
Number of authors \\
Number of sources used \\
\hline
\end{tabular}

\section{Result and Discussion}

In this part, the results of the physics education research are presented in sequence with their interpretations.

The distribution of physics education research articles when viewed from the year of publication

The distribution of data obtained from physics education research uploaded in 2018 to 2021 in terms of the year of publication can be found in see Table 2. Based on these data, it can be said that physics education research has increased the number of research results and is highest in 2021.

Table 2. The distribution of physics education research articles when viewed from the year of publication

\begin{tabular}{lll}
\hline Years & Frequency & Percentage \% \\
\hline 2018 & 5 & 10.42 \\
2019 & 10 & 20.83 \\
2020 & 10 & 20.83 \\
2021 & 23 & 47.92 \\
Total & 48 & 100 \\
\hline
\end{tabular}

The distribution of physics education research articles in terms of physics

The following data presents the physics materials used in physics education research. In the mixed category, the research article does not include what specific physics material is being studied. The articles only mention the subject matter used in the research is physics. Based on the picture below, it can be seen that the material that is most studied is wave material.

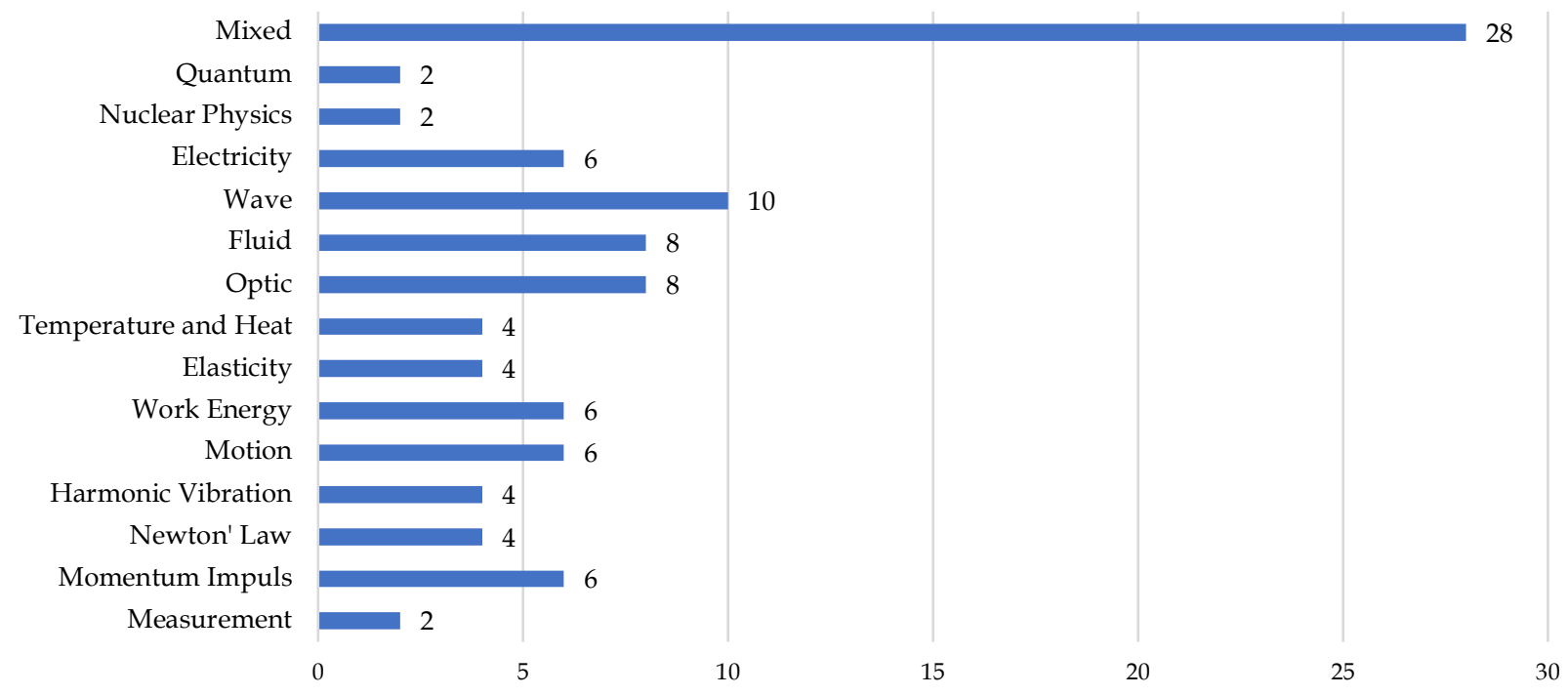

Figure 1. The distribution of physics education research articles in terms of physics 
The distribution of physics education research articles when viewed from the research variables used

The distribution of data obtained from physics education research published in 2018 to 2021 in terms of variables research used can be seen in Figure 2. Based on these data, it can be said that the most widely used physics education research variable is cognitive domain research with a result of $30.95 \%$. After the cognitive domain research, there are learning media $(25 \%)$, learning methods $(23.81 \%)$, domain research emotional (14.29\%), evaluation and assessment $(3.57 \%)$, and physics teacher training program $(2.38 \%)$.

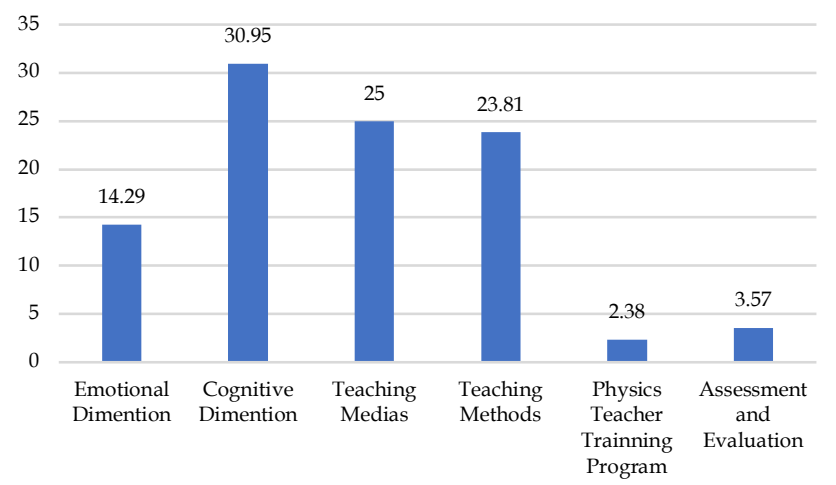

Figure 2. The distribution of physics education research articles when viewed from the research variables used

The distribution of physics education research articles when viewed from the research method

The distribution of data obtained from physics education research published in 2018 to 2021 in terms of research methods can be seen in Table 3. Based on these data, it can be said that the most widely used physics education research method is the quantitative research method with $47.92 \%$ results. After quantitative research methods, there are R\&D research methods $(33.33 \%)$, and qualitative research methods (18.75\%).

Table 3. The distribution of physics education research articles when viewed from the research method

\begin{tabular}{lll}
\hline Research Methods & Frequency & Percentage \% \\
\hline Qualitative & 9 & 18.75 \\
Quantitative & 23 & 47.92 \\
R\&D & 16 & 33.33 \\
Total & 48 & 100 \\
\hline
\end{tabular}

The distribution of physics education research articles in terms of research design

The distribution of data obtained from research in terms of research design can be seen in Table 4 . Based on these data, it can be said that the most widely used physics education research design is quasi-experimental design with $25 \%$ results.
Table 4. The distribution of physics education research articles in terms of research design

\begin{tabular}{|c|c|c|c|c|}
\hline \multicolumn{3}{|c|}{ Research Design } & \multirow{2}{*}{$\begin{array}{l}\mathrm{F} \\
12\end{array}$} & \multirow{2}{*}{$\begin{array}{l}\% \\
25.00\end{array}$} \\
\hline & Experimental & Quasi Experimental & & \\
\hline \multirow{2}{*}{ tative } & & Pre-Experimental & 6 & 12.50 \\
\hline & $\begin{array}{l}\text { Non-Experi- } \\
\text { mental }\end{array}$ & Descriptive & 5 & 10.42 \\
\hline \multirow{3}{*}{$\begin{array}{l}\text { Quali- } \\
\text { tative }\end{array}$} & & Descriptive & 7 & 14.58 \\
\hline & & Need Analysis & 1 & 2.08 \\
\hline & & Content Analysis & 1 & 2.08 \\
\hline \multirow[t]{5}{*}{ R\&D } & & DDD-E & 1 & 2.08 \\
\hline & & Borg\&Gall & 2 & 4.17 \\
\hline & & $4 \mathrm{D}$ & 7 & 14.58 \\
\hline & & Dick\&Carey & 2 & 4.17 \\
\hline & & ADDIE & 4 & 8.33 \\
\hline Total & & & 48 & 100 \\
\hline
\end{tabular}

The distribution of physics education research articles in terms of data collection instruments

The distribution of data obtained from physics education research uploaded in 2018 to 2021 in terms of data collection instruments can be seen in Table 5. Based on these data, it can be said that the most widely used physics education research data collection instrument is the test instrument with a result of $37.33 \%$; a questionnaire with a Likert scale (32\%); and observation sheets $(17.33 \%)$.

Table 5. The distribution of physics education research articles in terms of data collection instruments

\begin{tabular}{lll}
\hline Data Collection Instruments & Frequency & $\%$ \\
\hline Multiple Choice Questionnaire & 1 & 1.33 \\
Open Ended Questionnaire & 2 & 2.67 \\
Likert Type Questionnaire & 24 & 32.00 \\
Dichotomus Scale Questionnaire & 1 & 1.33 \\
Test & 28 & 37.33 \\
Interview & 4 & 5.33 \\
Documents & 2 & 2.67 \\
Observation & 13 & 17.33 \\
\hline
\end{tabular}

The distribution of data collection instruments can also be seen in Figure 3. The use of one data collection instrument is mostly used in physics education research with a value of $26 \%$. The use of two data collection instruments with a value of $13 \%$ and three or more data collection instruments of $9 \%$.

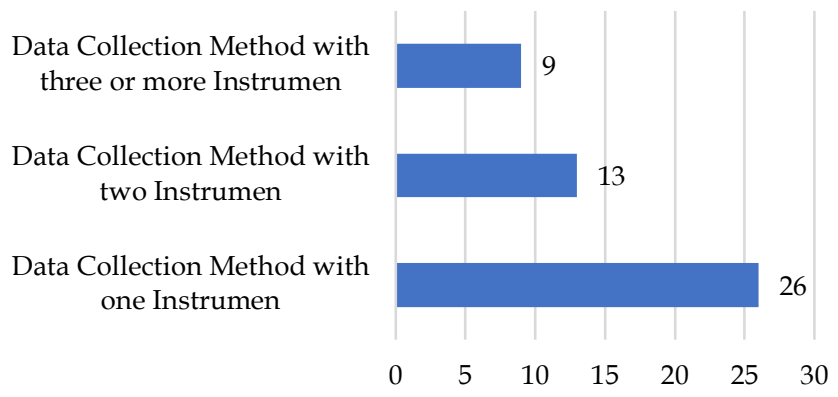

Figure 3. The distribution of physics education research articles in terms of data collection instruments 
The distribution of physics education research articles when viewed from the type of sampling

The distribution of data obtained from physics education research uploaded from 2018 to 2021 in terms of sampling type can be seen in Figure 4. Based on these data, it can be said that the most widely used type of physics education research sampling is research on school students with a result of $56.60 \%$.

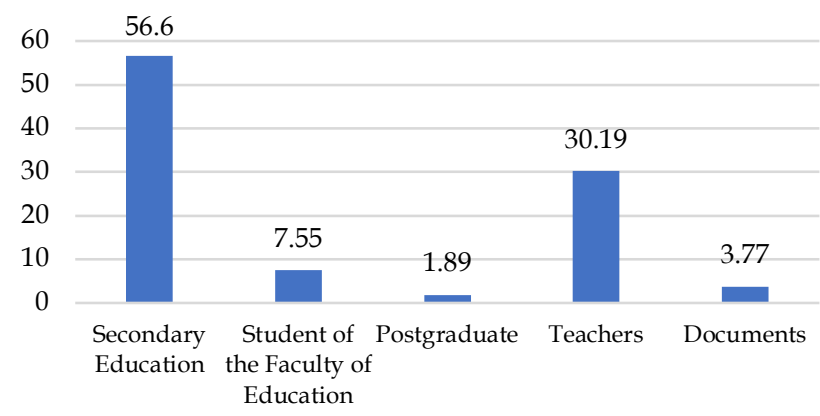

Figure 4. The distribution of physics education research articles when viewed from the type of sampling

The distribution of physics education research articles when viewed from data analysis techniques

The distribution of data obtained from physics education research uploaded in 2018 to 2021 in terms of data analysis techniques can be seen in Table 6 . Based on these data, it can be said that the most widely used physics education research data analysis technique is descriptive quantitative in the form of frequency. percentages, and charts with $29.49 \%$ results.

Table 6. The distribution of physics education research articles when viewed from data analysis techniques

\begin{tabular}{|c|c|c|c|c|}
\hline \multicolumn{3}{|c|}{ Data Analysis Method and Techniques } & $\mathrm{F}$ & $\%$ \\
\hline \multirow{13}{*}{$\begin{array}{l}\text { Quanti- } \\
\text { tative }\end{array}$} & \multirow[t]{5}{*}{ Descriptive } & Frequency/ & 23 & 29.49 \\
\hline & & Percentage/ & & \\
\hline & & Chart & & \\
\hline & & Mean/Standart & 8 & 10.26 \\
\hline & & Deviation & & \\
\hline & \multirow[t]{8}{*}{ Predictive } & T-test & 13 & 16.67 \\
\hline & & N-Gain & 17 & 21.79 \\
\hline & & ANOVA & 3 & 3.85 \\
\hline & & ANCOVA & & \\
\hline & & Correlation & 2 & 2.56 \\
\hline & & Regression & 1 & 1.28 \\
\hline & & MANOVA & 2 & 2.56 \\
\hline & & MANCOVA & & \\
\hline \multirow{3}{*}{$\begin{array}{l}\text { Quali- } \\
\text { tative }\end{array}$} & & Descriptive & 7 & 8.97 \\
\hline & & Analysis & & \\
\hline & & Content Analysis & 2 & 2.56 \\
\hline
\end{tabular}

The distribution of data analysis techniques can also be seen in Figure 5. The use of one data analysis technique is more widely used in physics education research with a value of $22 \%$. The use of two data analysis techniques with a value of $21 \%$ and three or more data analysis techniques $5 \%$.

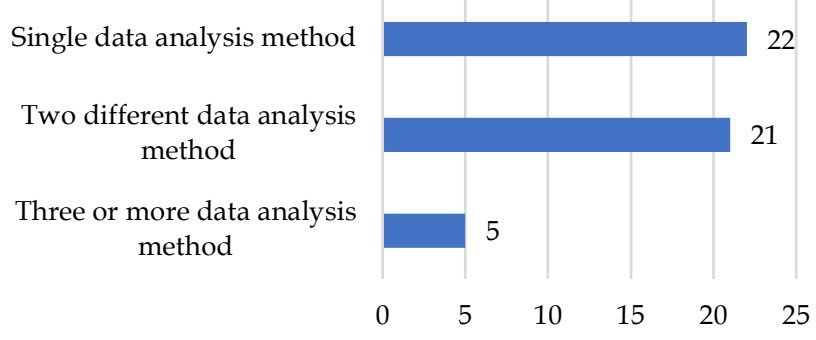

Figure 5. The distribution of physics education research articles when viewed from data analysis

The distribution of physics education research articles when viewed from the number of authors

The distribution of data obtained from physics education research uploaded in 2018 to 2021 in terms of the number of authors can be seen in Table 7 . Based on these data, it can be said that the number of authors of physics education research at most is three authors with a result of $52.08 \%$.

Table 7. The distribution of physics education research articles when viewed from the number of authors

\begin{tabular}{lll}
\hline Author Number & Frequency & Percentage \% \\
\hline 1 & 1 & 2.08 \\
2 & 5 & 10.42 \\
3 & 25 & 52.08 \\
4 & 10 & 20.83 \\
5 & 3 & 6.25 \\
6 & 1 & 2.08 \\
7 & 3 & 6.25 \\
Total & 48 & 100 \\
\hline
\end{tabular}

The distribution of physics education research articles when viewed from the number of references used

The distribution of data obtained from physics education research uploaded in 2018 to 2021 in terms of the number of references used can be seen in Table 8 . Based on these data, it can be said that the number of references used in physics education research is the most, amounting to 1-30 references with a result of $91.67 \%$.

Table 8. The distribution of physics education research articles when viewed from the number of references used

\begin{tabular}{lll}
\hline Source Number & Frequency & Percentage $\%$ \\
\hline $1-30$ sources & 44 & 91.67 \\
$31-60$ sources & 4 & 8.33 \\
Total & 48 & 100 \\
\hline
\end{tabular}

This research is content analysis research. This type of research can contribute to showing the identity of education and provide concrete recommendations for further research (Choi, et al., 2016; Dewi \& Jauhariyah, 2021). The data source in this study was research articles 
in the field of physics education published in the Journal of Research of Science Education (JPPIPA) UNRAM West Nusa Tenggara from 2018 to 2021, totaling 48 physics education research articles.

Educational research trends and trends are always changing from time to time. This change follows the phenomenon of educational problems that are developing in the field (Pujianto \& Suyoso, 2011). Research topics tend to disappear and certain topics tend to reappear. The focus of science education research in developed countries is changing in line with the science education reforms being carried out by these countries. It can be seen in the results of the study where in 2021 the trend of physics education research will increase. This proves that research trends in physics education have attracted researchers. In this study, it can be seen based on the data that the trend of physics education research tends to physics material, namely wave material. Waves are one of the important materials studied in physics. The wave material is studied in several sub-materials, causing the level of understanding of students' concepts to be difficult (Istyowati, et al., 2017). This is what makes researchers in the field of physics education tend to choose wave material.

Based on the data obtained from this study, the trend of physics education research tends to research in the cognitive domain. The school curriculum in Indonesia makes the cognitive aspect an important element and becomes the main thing that becomes the goal or target of learning activities, so educators are required to be able to design learning in such a way that can facilitate students in developing their cognitive abilities (Dahlan, et al., 2020). A good quality of education is obtained by applying all levels of the cognitive domain in every learning activity. The trend of physics education research tends to be research that uses quantitative research methods. This can be seen in Table 3. Quantitative research method is a method for examining a population or sample using instruments in collecting data (Mulyadi, 2011; Yusup, 2018). Quantitative research aims to provide a clear description of the problem that is thorough and can explain the data clearly and systematically (Pratomo, 2017). This makes quantitative research favored by many researchers to be used in their research.

In this study, it can be seen based on the data that the trend of physics education research tends to be quantitative research with aresearch quasi-experimental design. This type of research is aimed at knowing the effect of a treatment (Sugiyono, 2016). So, quasiexperimental widely used by researchers in the field of physics education because it can see the impact of a treatment on the subject under study. Based on the data obtained from this study, the trend of physics education research tends to be research that uses data collection instruments in the form of test instruments. The test instrument is defined as an experiment that is held to determine whether or not there are certain learning outcomes for a student or group (Arikunto, 2021). The test instrument is widely used by physics education researchers because it is considered systematic and objective to obtain data or information that can be said to be precise and fast.

The trend of physics education research tends to be research that uses a sampling type of school students, both junior and senior high school students. This can be seen in Figure 4. Based on the data displayed, it can be concluded that physics education researchers prefer samples from junior high and high school students because many studies have been carried out to find out the response of a treatment to middle and high school students. In this study, it can be seen based on the data that the trend of physics education research tends to quantitative descriptive research with data analysis techniques using frequencies, percentages, and charts. This makes it easier for researchers and future researchers to read the data from the analysis of the research that has been done.

Based on the data obtained from this study, physics education research trends tend to research that uses the number of the author or authors of three people. Therefore, it is recommended to increase the number of authors in future studies because this will increase the level of collaboration between researchers to work together to produce a better research. The trend of physics education research tends to be research that uses only 1-30 research references. This can be seen in Table 8. Therefore, it is recommended to conduct a more detailed literature review and use more sources updated because it will be very useful in following developments in the field of physics education research with wider sources.

The results of content analysis research are believed to be a guide for researchers and educators in conveying information about subjects, research techniques and data analysis methods used in physics education research. In addition, taking into account the low number of content analysis in the field of physics education, it can be concluded that the continuity of examining the research tendencies of physics education researchers will increase the tendency towards research in this field and can also guide and provide references for research to be carried out by future researchers, especially in the field of physics education research.

\section{Conclusion}

Based on the results of the research that has been carried out, it can be concluded that the trend of educational research has increased and is in great demand by researchers in 2021. The physics material 
that is the research trend is wave material. The subject variable that is often studied is research in the cognitive domain. The trend of physics education research tends to be research that uses quantitative research methods with quasi-experimental design and uses data collection instruments in the form of test instruments. The type of sampling used is school students both junior and senior high school. The trend of physics education research also tends to quantitative descriptive research with data analysis techniques using frequencies, percentages, and charts. Number author or authors are becoming a trend in physics education research as much as three and the number of research references are often used as reference only 1-30. The results of this analytical research can be used to guide and provide references for research that will be carried out by further researchers, especially in the field of physics education research.

\section{References}

Abbas, A., \& Hidayat, M. Y. (2018). Faktor-faktor kesulitan belajar fisika pada peserta didik kelas IPA sekolah menengah atas. Jurnal Pendidikan Fisika, 6(1), 45-50. https:// doi.org/10.24252/jpf.v6i1.3273

Arici, F., Yildirim, P., Caliklar, Ş., \& Yilmaz, R. M. (2019). Research trends in the use of augmented reality in science education: Content and bibliometric mapping analysis. Computers \& Education, 142, 103647.

https:// doi.org/10.1016/j.compedu.2019.103647

Arikunto, S. (2021). Dasar-Dasar Evaluasi Pendidikan Edisi 3. Bumi Aksara.

Asmawati, E. Y. S., Rosidin, U., \& Abdurrahman, A. (2018). Efektivitas Instrumen Asesmen Model Creative Problem Solving pada Pembelajaran Fisika Terhadap Kemampuan Berpikir Kritis Siswa. Jurnal Pendidikan Fisika, 6(2), 128-143. http://dx.doi.org/10.24127/jpf.v6i2.1318

Astalini, A., Kurniawan, D. A., Perdana, R., \& Pathoni, H. (2019). Identifikasi sikap peserta didik terhadap mata pelajaran fisika di sekolah menengah atas negeri 5 Kota Jambi. UPEJ Unnes Physics Education Journal, 8(1), 34-43. https://doi.org/10.15294/upej.v8i1.29510

Azizah, R., Yuliati, L., \& Latifah, E. (2015). Kesulitan pemecahan masalah fisika pada siswa SMA. Jurnal penelitian fisika dan aplikasinya (JPFA), 5(2), 44-50. https:// doi.org/10.26740/ipfa.v5n2.p44-50

Borenstein, M., Hedges, L. V., Higgins, J. P., \& Rothstein, H. R. (2021). Introduction to meta-analysis. John Wiley \& Sons.

Calik, M., \& Sözbilir, M. (2014). Parameters of content analysis. Egitim ve Bilim, 39(174). https://doi.org/10.15390/EB.2014.3412

Choi, S. H., Seo, H. J., \& Kim, Y. S. (2016). Analysis of the research trends of the Korean journal of educational research using network text analysis. International Journal of Software Engineering and Its Applications, 10(12), 169-178. http://dx.doi.org/10.14257/ijseia.2016.10.12.14

Dahlan, A., Herman, H., \& Yani, A. Analisis Kemampuan Kognitif dalam Menyelesaikan SoalSoal Fisika Peserta Didik SMAN 21 Makassar. Jurnal Sains dan Pendidikan Fisika, 17(2), 146-152. https://doi.org/10.35580/jspf.v17i2.26144

Darmalaksana, W., \& Suryana, Y. (2018). Korespondensi dalam publikasi ilmiah. Jurnal Perspektif, 1(2). http://dx.doi.org/10.15575/jp.v1i2.10

Dewi, I. S., \& Jauhariyah, M. N. R. (2021). Analisis Bibliometrik Implementasi Pembelajaran Fisika Berbasis STEM pada Tahun 2011-2021. Jurnal Ilmiah Pendidikan Fisika, 5(3), 368-387. https://doi.org/10.20527/jipf.v5i3.3904

Dinçer, S. (2018). Content Analysis in Scientific Research: Meta-Analysis, Meta-Synthesis, and Descriptive Content Analysis. Bartin University Journal of Faculty of Education, 7(1), 176-190. https://doi.org/10.14686/buefad.363159

Goktas, Y., Kucuk, S., Aydemir, M., Telli, E., Arpacik, O., Yildirim, G., \& Reisoglu, I. (2012). Educational technology research trends in Turkey: A content analysis of the 2000-2009 decade. Educational Sciences: Theory and Practice, 12(1), 191-199.

Habibi, M., Zainuddin, Z., \& Misbah, M. (2017). Pengembangan Perangkat Pembelajaran IPA Fisika Berorientasi Kemampuan Pemecahan Masalah Menggunakan Model Pengajaran Langsung pada Pokok Bahasan Tekanan. Berkala Ilmiah Pendidikan Fisika, 5(1), 1-17. http://dx.doi.org/10.20527/bipf.v5i1.2234

Hoellwarth, C., Moelter, M. J., \& Knight, R. D. (2005). A direct comparison of conceptual learning and problem-solving ability in traditional and studio style classrooms. American Journal of physics, 73(5), 459-462. https://doi.org/10.1119/1.1862633

Istyowati, A., Kusairi, S., \& Handayanto, S. K. (2017). Analisis pembelajaran dan kesulitan siswa SMA kelas xi terhadap penguasaan konsep Fisika. Research Report.

Kalsum, U., Hartini, S., \& Miriam, S. (2018). Hubungan Kecerdasan Emosional Dengan Kemampuan Pemecahan Masalah Fisika Siswa Kelas IX SMP Negeri 24 Banjarmasin. Jurnal Ilmiah Pendidikan Fisika http://dx.doi.org/10.20527/jipf.v2i2.1008

Martono, N. (2016). Metode peneliian kuantitatif: Analisis isi dan analisis data sekunder: Edisi revisi 2. Jakarta: RajaGrafindo Persada.

Mardhiyah, R. H., Aldriani, S. N. F., Chitta, F., \& Zulfikar, M. R. (2021). Pentingnya Keterampilan Belajar di Abad 21 sebagai Tuntutan dalam Pengembangan Sumber Daya Manusia. Lectura: 
Jurnal Pendidikan, 12(1), 29-40. https://doi.org/10.31849/lectura.v12i1.5813

Mulyadi, M. (2011). Penelitian kuantitatif dan kualitatif serta pemikiran dasar menggabungkannya. Jurnal studi komunikasi dan media, 15(1), 128-137. http://dx.doi.org/10.31445/jskm.2011.150106

Ogilvie, C. A. (2009). Changes in students' problemsolving strategies in a course that includes contextrich, multifaceted problems. Physical Review Special Topics-Physics Education Research, 5(2), 020102. https://doi.org/10.1103/PhysRevSTPER.5.020102

Patonah, S., Nuvitalia, D., \& Saptaningrum, E. (2018). Content analysis of science material in junior school-based inquiry and science process skills. In Journal of Physics: Conference Series 983(1), p. 012167. IOP Publishing. https://doi.org/10.1088/17426596/983/1/012167

Pratomo, Y. I. F. (2017). Kepuasan Pengguna Layanan Kesehatan RSUD Kota Surakarta (Studi Deskriptif Kuantitatif Tingkat Kepuasan Pasien Rawat Jalan RSUD Kota Surakarta). Thesis. Universitas Sebelas Maret

Pujianto, \& Suyoso. (2011). Analisis Kecendrungan dan Tren Penelitian Pada Mahasiswa Pendidikan Fisika Sebagai Revitalisasi Bidang Keahlian Penunjang Akreditasi: Studi Kasus Prodi Pendidikan Fisika FMIPA UNY. Prociding Seminar Nasional Sains. Universitas Negeri Yogyakarta

Redish, E. F. (2005). Changing student ways of knowing: What should our students learn in a physics class. Proceedings of World View on Physics Education, 1-13.

Sari, N., Sunarno, W., \& Sarwanto, S. (2018). Analisis motivasi belajar siswa dalam pembelajaran fisika sekolah menengah atas. Jurnal Pendidikan dan Kebudayaan, 3(1), 260934. https://doi.org/10.24832/jpnk.v3i1.591

Siswanto, J. (2020). Mempersiapkan Society 5.0 melalui Pembelajaran Fisika. In SNPF (Seminar Nasional Pendidikan Fisika).

Sugiyono. (2016).Metode Penelitian Kuantitatif, Kualitatif, dan RED.Bandung: Alfabeta.

Sudjana, N., \& Ibrahim. (2004). Penelitian dan penilaian pendidikan. Bandung: Sinar Baru Algensindo Offset.

Sulistyaningrum, H., Winata, A., \& Cacik, S. (2019). Analisis Kemampuan Awal 21st Century Skills Mahasiswa Calon Guru SD. Jurnal Pendidikan Dasar Nusantara, 5(1), 142-158. https://doi.org/10.29407/jpdn.v5i1.13068

Wijaya, E. Y., Sudjimat, D. A., Nyoto, A., \& Malang, U. N. (2016). Transformasi pendidikan abad 21 sebagai tuntutan pengembangan sumber daya manusia di era global. In Prosiding Seminar Nasional Pendidikan Matematika. 1(26), 263-278.

Winarti, W. (2020, January). Peran Pendidik Fisika Dalam Mempersiapkan Society 5.0. In SNPF (Seminar Nasional Pendidikan Fisika).
Yusup, F. (2018). Uji validitas dan reliabilitas instrumen penelitian kuantitatif. Tarbiyah: Jurnal Ilmiah Kependidikan, http://dx.doi.org/10.18592/tarbiyah.v7i1.2100 